\title{
Review: Pengaruh Pakan Terhadap Kualitas Semen Ayam
}

\author{
Cecep Hidayat ${ }^{1}$, Soni Sopiyana ${ }^{1}$, Rahman $^{2 *}$ \\ ${ }^{1}$ Balai Penelitian Ternak, PO Box 221, Bogor 16002 \\ ${ }^{2}$ Fakultas Peternakan, Universitas Halu Oleo \\ Kampus Hijau Bumi Tridharma, Jl. H.E.A. Mokodompit, Anduonohu, Kendari 93232 \\ *Email korespondensi: rahman@uho.ac.id
}

(Diterima 11-04-2020; disetujui 20-09-2020)

\begin{abstract}
ABSTRAK
Semen adalah cairan yang dikeluarkan oleh organ kelamin ternak jantan yang secara normal diejakulasikan ke dalam saluran reproduksi ternak betina melalui kopulasi. Evaluasi semen merupakan alat utama untuk memprediksi kinerja reproduksi ternak ayam jantan. Evaluasi kualitas semen penting dilakukan untuk menyelesaikan salah satu masalah utama dalam peternakan pembibitan ayam, yaitu rendahnya fertilitas. Faktor terbesar dari sumber masalah tersebut terkait dengan rendahnya kualitas semen ayam. Kualitas semen ayam lebih banyak dipengaruhi oleh faktor non genetik, seperti faktor pakan dan nutrisi. Tujuan dari penulisan makalah ini adalah untuk mengkaji hasil-hasil studi terkait pengaruh pakan terhadap kualitas semen ayam. Hasil studi menunjukkan bahwa faktor pakan sangat mempengaruhi kualitas semen ayam, terutama imbangan energi metabolis-protein dalam pakan ayam jantan sangat penting diatur untuk menjaga berat badan ayam jantan agar tidak terjadi kelebihan atau kekurangan berat badan yang sangat mempengaruhi kualitas semen ayam. Suplementasi suplemen dan imbuhan pakan menjadi upaya yang dapat dilakukan untuk meningkatkan kualitas semen ayam. Jenis suplementasi yang dapat dilakukan dengan bahan sumber antioksidan, asam amino, mikromineral, bahan mengandung bioaktif tanaman, bahan sumber asam lemak dan probiotik. Disimpulkan bahwa faktor pakan sangat menentukan terhadap kualitas semen ayam.
\end{abstract}

Kata kunci: ayam jantan, kualitas semen, pakan

\begin{abstract}
Rooster semen is a liquid released by the genitals of the roosters which is normally ejaculated into the female reproductive tract during copulation. Semen evaluation is the main way to predict the reproductive performance of roosters. Semen quality evaluation is important to solve one of the main problems in poultry breeding farms, namely low fertility, whereas the biggest factor of this problem source is related to the poor of roosters' semen quality. The quality of roosters semen is more influenced by non-genetic factors, such as feed and nutrition. The purpose of this paper was to examine the results of studies so far related to the effect of feed on the roosters' semen quality. The results of the study indicated that the feed factor greatly influences the quality of roosters semen. The metabolic energy-protein balance in the rooster's feed was very important to regulate to maintain the weight of the rooster so as not to overweight and underweight because bodyweight greatly affects the quality of roosters semen. Supplementation of feed supplements and feed additives was an effort that can be done to improve the roosters semen quality. The kind of supplementation that could be done was supplementation of antioxidant sources, amino acids, microminerals, materials containing plant bioactive, fatty acid source ingredients, and probiotics. It was concluded that the feed factor was crucial to the quality of semen quality produced by the roosters.
\end{abstract}

Keywords: feed, rooster, semen quality

\section{PENDAHULUAN}

Fertilitas adalah syarat pertama dan terpenting pada peternakan perbibitan ternak ayam. Peternakan perbibitan ayam menghasilkan telur fertile (subur) merupakan tahapan penting dalam rangka menghasilkan produksi bibit ayam yang maksimal. Semakin banyak jumlah telur fertil yang dihasilkan, maka semakin banyak potensi dihasilkannya day old chick (DOC), artinya keuntungan ekonomi akan semakin besar yang 
dihasilkan pada suatu industri peternakan perbibitan ayam dan sebaliknya, kerugian ekonomi akan diperoleh ketika dihasilkan telur yang tidak fertile. Berdasarkan penjelasan tersebut, maka produksi maksimum jumlah telur fertil menjadi perhatian penting para peternak pembibit (Akhlaghi et al., 2014). Ternak ayam jantan dilaporkan lebih memiliki peran lebih terhadap capaian tingkat fertilitas, meskipun ternak ayam jantan dan betina memainkan peran penting terhadap tingkat fertilitas telur (Leeson \& Summers, 2009). Salah satu masalah utama dalam pembibitan ternak ayam adalah rendahnya fertilitas dan sekitar 30\% disebabkan oleh dari sumber masalah tersebut terkait dengan kualitas semen ayam (Okoro, et al., 2016).

Soi, (2016) menjelaskan bahwa semen adalah cairan yang dikeluarkan oleh alat kelamin jantan yang secara normal diejakulasikan ke dalam saluran reproduksi hewan betina sewaktu kopulasi. Kualitas semen pada ayam adalah kombinasi dari berbagai karakteristik kuantitatif seperti konsentrasi sel spermatozoa, motilitas sel spermatozoa, volume semen, dan karakteristik ini diwariskan (Dasrul \& Thasmi, 2017). Iswati et al. (2017) menjelaskan bahwa kualitas semen, dapat ditingkatkan dengan beberapa pendekatan yaitu breeding, manajemen lingkungan (temperatur dan kandang), nutrisi, frekuensi koleksi semen, serta teknik inseminasi buatan. Al Mahdi et al. (2014) mengatakan bahwa volume semen unggas relatif sedikit dan konsentrasi spermatozoa cukup tinggi. Hal ini terjadi, karena ternak unggas tidak memiliki aksesoris kelenjar seperti mamalia yang menyebabkan volume plasma semen unggas menjadi rendah. Perbedaan volume semen per ejakulasi ternak unggas dipengaruhi oleh perbedaan breed, ukuran tubuh, asupan gizi, suhu lingkungan, umur, dan kekurangan tidaknya terhadap vitamin A dan E. Soi (2016) mengatakan bahwa efisiensi reproduksi ayam lebih banyak dipengaruhi oleh faktor non genetik, seperti faktor nutrisi.

Iswati et al. (2017) megatakan bahwa evaluasi semen merupakan alat utama untuk memprediksi kinerja reproduksi ternak unggas jantan. Prieto et al. (2011) mengatakan bahwa kualitas semen ayam dipengaruhi oleh suhu lingkungan. Kisaran suhu lingkungan optimal yang mendukung kinerja reproduksi ayam adalah 18$22^{\circ} \mathrm{C}$. Kualitas semen yang tinggi akan menghasilkan fertilitas tinggi, sehingga meningkatkan daya tetas telur sebagai penghasil sumber bibit (DOC). Wahyuni et al. (2017) mengatakan bahwa komponen utama indikator untuk menentukan kualitas semen adalah motilitas, konsentrasi dan kelainan (abnormality). Komponen-komponen tersebut berada di bawah kontrol banyak faktor, termasuk pakan. Pendekatan manajemen pakan dan nutrisi, seperti penambahan berbagai suplemen, imbuhan pakan dan lainnya untuk meningkatkan kualitas semen ayam telah banyak dilaporkan (Okoro et al., 2016; Akhlaghi et al., 2014). Tujuan dari penulisan makalah ini adalah untuk mengkaji hasil-hasil studi terkait pengaruh pakan terhadap kualitas semen ayam.

\section{FAKTOR-FAKTOR YANG MEMPENGARUHI KUALITAS SEMEN AYAM}

Danang et al. (2012) melaporkan bahwa volume semen menurun seiring bertambahnya umur pada ayam jantan yang berhubungan dengan konsentrasi spermatozoa. Leeson \& Summers (2009) mengatakan bahwa kesuburan ayam jantan mulai menurun sejak umur 40 minggu. Ansari et al. (2018) mengatakan bahwa ayam jantan tua menurun kemampuan pembuahannya diakibatkan oleh beberapa faktor, yaitu pertambahan berat badan, penurunan konsentrasi semen, tingkat sirkulasi testosteron yang lebih rendah, disfungsi sel sertoli dan penurunan total kapasitas antioksidan semen. Semen terdapat dua bagian utama, yaitu sel-sel gamet jantan atau spermatozoa dan plasma semen (Garner \& Hafez, 2008). Spermatozoa dihasilkan di dalam testis melalui spermatogenesis. Ardhani et al. (2018) melaporkan bahwa struktur spermatozoa unggas terbagi ke dalam beberapa bagian, yaitu kepala, bagian tengah dan ekor. Spermatozoa memiliki panjang $100 \mu \mathrm{m}$, dengan rincian panjang tiap bagian, sebagai berikut, ukuran bagian kepala, akrosom, bagian tegah dan bagian ekor spermatozoa berturut-turut adalah 12,$5 ; 1,75 ; 4$; dan $80 \mu \mathrm{m}$ dengan diameter bagian tengah dan kepala $0.5 \mu \mathrm{m}$ (Ardhani et al. 2018). Hoesni (2016) mengatakan bahwa plasma semen memiliki fungsi sebagai sarana transportasi spermatozoa saat ejakulasi dan sebagai penyangga (buffer) spermatozoa agar tetap hidup sesudah dideposisikan ke dalam saluran reproduksi betina. Senyawa yang terkandung dalam plasma semen adalah senyawat organik dan inorganik. Ardhani et al. (2018) melaporkan bahwa senyawa organik yang menyusun plasma semen adalah sperumine, ergothionine, phosporicholine, asam sitrat, glyceryl phosporicholine, sorbitol, inositol dan fruktosa. Plasma semen juga mengandung senyawa-senyawa inorganik, yaitu kalsium, bikarbonat dan kalium. 
Fungsi reproduksi pada ayam jantan adalah endokrin yang dikendalikan oleh hipofisis dan testis (Mc Govern, 2002). Senger (2003) menjelaskan bahwa produksi sperma dimulai oleh sekresi Gonadotropin Releasing Hormone ( $\mathrm{GnRH})$ dari hipotalamus, sekresi Luteinizing Hormone (LH) dan Follicle Stimulating Hormone (FSH) oleh lobus anterior hipofisis dan sekresi steroid gonad (testosteron dan estrogen). Luteinizing Hormone bertindak pada sel-sel Leydig di dalam testis untuk merangsang produksi progesteron, yang diubah menjadi hormon seks jantan testosteron. Testosteron dalam tubulus seminiferus sangat penting untuk spermatogenesis, sedangkan sel leydig terkait dengan pertahanan kadar LH. Bearden et al. (2004) menjelaskan bahwa testis dikelilingi oleh lapisan jaringan ikat yang mengandung tubulus seminiferus dan sel leydig. Beberapa androgen diproduksi di sel interstitial testis, tetapi hormon utama dalam darah adalah testosteron. Testosteron sangat penting untuk pengembangan karakteristik seks sekunder dan untuk perilaku kawin normal pada ternak jantan. Testosteron juga diperlukan untuk berfungsinya kelenjar-kelenjar aksesori, produksi spermatozoa dan pemeliharaan sistem saluran jantan. Hormon ini juga membantu spermatocytogenesis, pengangkutan spermatozoa dan deposisi semen dalam saluran reproduksi betina. Ardhani et al. (2018) mengatakan bahwa ketika ayam jantan mencapai dewasa kelamin, produksi testosteron dirangsang dengan meningkatnya konsentrasi gonadotropin. Estrogen, selain testosteron, juga berperan dalam pengembangan dan fungsi dari testis dan saluran reproduksi ternak jantan. Guo et al. (2016) menjelaskan bahwa gonadotropin utama yang terlibat adalah FSH dan LH, juga disebut Interstitial Cell Stimulating Hormone (ICSH) pada ternak jantan. Dua hormon gonadotropik disekresi oleh hipofisis anterior. Follicle stimulating hormone bekerja pada sel germinal dalam tubulus seminiferus testis dan mendukung spermatogenesis ke tahap spermatosit sekunder.

Faktor internal dan eksternal yang mempengaruhi produksi semen atau volume semen yang diejakulasikan. Qazi et al. (2019) mengatakan bahwa faktor-faktor eksternal tertentu yang mempengaruhi efisiensi reproduksi ayam jantan dapat dikelompokkan menjadi dua kategori, pertama, sebagai pengaruh dari pakan, manajemen, dan proses fisiologis normal yang mengatur aktivitas spermatogenesis. Kedua, faktor yang mempengaruhi ayam jantan akan merespon teknik pijat selama pengeluaran semen. Adamu et al. (2019) mengatakan bahwa perbedaan volume dan konsentrasi spermatozoa semen unggas sangat tergantung pada kontribusi relatif dari berbagai kelenjar reproduksi, jumlah spermatozoa yang dapat diperoleh dari suatu breed atau strain dan sejauh mana potensi genetiknya yang dapat dimaksimalkan. Tesfay et al. (2020) melaporkan bahwa breed dan waktu pengumpulan semen mempengaruhi volume semen ayam. Akingbemi (2005) mengatakan bahwa semen berkualitas tinggi ditentukan oleh kondisi spermatogenesis yang normal.

\section{PENGARUH KANDUNGAN ENERGI METABOLIS DAN PROTEIN PAKAN TERHADAP KUALITAS SEMEN AYAM}

Romero-Sanchez et al. (2008) melaporkan bahwa kandungan gizi pakan, terutama kandungan energi-protein, mempengaruhi produksi dan kualitas semen ayam jantan. Kandungan gizi pakan terkait dengan fungsi reproduksi ayam jantan, karena kandungan gizi pakan sangat berkaitan dengan capaian berat badan ayam jantan. Banyak dilaporkan bahwa obesitas pada ayam jantan menurunkan kinerja fungsi reproduksi. McGovern (2002) menemukan bahwa obesitas pada ternak ayam terkait dengan penurunan kesuburan. Sementara itu, Patil (2014) melaporkan bahwa terjadi masalah kesuburan pada ayam jantan yang kelebihan atau kekurangan berat badan. Djermanovic et al. (2013) mengatakan bahwa terdapat hubungan negatif antara berat badan ayam jantan dengan aktivitas kawin dan antara berat badan ayam jantan dengan tingkat fertilitas. Berdasarkan fakta tersebut, maka, perlunya program manajemen nutrisi dalam peternakan pembibitan ayam. Laporan Marie et al. (2009) menunjukkan bahwa pakan dengan kandungan energi metabolis rendah menyebabkan peningkatan berat badan yang berlebihan, hal ini disebabkan oleh ayam yang diberi pakan dengan kandungan energi metabolis rendah akan mengkonsumsi pakan lebih banyak yang berakibat pada konsumsi zat gizi (terutama protein, vitamin dan mineral) yang lebih tinggi. Kondisi tersebut menginduksi kematangan seksual awal dan mengurangi kesuburan ayam jantan. Mahmoodpour et al. (2017) melaporkan bahwa peningkatan asupan kalori dapat menyebabkan peningkatan berat testis tanpa peningkatan efisiensi spermatogenik. Oleh karena itu, asupan nutrisi yang tepat sangat penting untuk menjaga kinerja reproduksi ayam jantan. Tabatabaei et al. (2010) menunjukkan bahwa volume semen menurun seiring dengan bertambahnya umur dan penurunan berat badan 
ayam jantan. Penurunan volume ejakulasi akibat bertambahnya umur ayam mendukung hasil penelitian sebelumnya yang melaporkan bahwa ejakulasi semen ayam jantan menurun seiring dengan menurunnya berat badan (Fouad et al. 2020). Envan et al. (2008) melaporkan bahwa konsumsi $55 \mathrm{kkal} \mathrm{ME} / \mathrm{kg}$ berat badan dalam satu hari, cukup untuk mempertahankan berat badan.

Beberapa laporan menunjukkan bahwa kinerja pertumbuhan yang tinggi mengarah ke pematangan seksual lebih awal (El-Dlebshany, 2008; Brière et al. 2011). Kenaikan berat badan yang tinggi selama periode pra-pubertas tampaknya melibatkan percepatan peningkatan ukuran testis. Hal ini dapat dikaitkan dengan perkembangan tubulus seminiferus didalam testis. Faktanya, selama periode pra-pubertas, perkembangan testis sangat terkait dengan jumlah dan ukuran sel Sertoli, sementara itu, perkembangan testis berkorelasi dengan jumlah sel germinal pada periode pubertas. Hal ini sesuai dengan laporan Moyle et al. (2012) melaporkan bahwa peningkatan berat testis tidak diikuti dengan peningkatan produksi spermatozoa. Testis menghasilkan spermatozoa dan plasma semen menunjukkan bahwa perkembangan testis tidak hanya terkait dengan proliferasi sel Sertoli tetapi juga dengan pembentukan aktivitas spermatogenesis (Lüpold et al. 2011). Asupan energi tinggi dari pakan akan mempercepat pengembangan prapubertas, mempercepat terjadinya spermatogenesis, sehingga menyebab-kan terjadinya pubertas dini. Karakteristik semen ayam jantan yang diberi makan dengan energi makanan tertinggi (3100 $\mathrm{KalME} / \mathrm{kg}$ ) relatif lebih rendah, apabila dibandingkan dengan ayam yang diberi pakan dengan kandungan energi metabolis terendah (2800 KalME/kg) (Tadondjou et al., 2013). Brière et al. (2011) melaporkan bahwa hipertermia intratestikuler yang dihasilkan dari asupan energi tinggi dapat menurunkan produksi spermatozoa. Pemberian pakan dengan kandungan energi metabolis tinggi akan mengurangi produksi spermatozoa dengan mengurangi kemampuan spermatogonia untuk berkembang menjadi spermatosit I dan II.

Djermanovic et al. (2013) melaporkan bahwa manajemen berat badan pada ternak ayam jantan sangat penting untuk menjaga fertilitas dan manajemen berat badan sering dicapai dengan mengatur kandungan protein kasar (PK) dan teknik pembatasan pakan. Laporan Chen et al. (2006) bahwa obesitas pada induk ayam betina menurunkan fertilitas akibat disfungsi ovarium yang dibuktikan dengan menurunnya produksi telur dan serta penurunan kualitas kulit telur. Hal yang sama juga terjadi pada ternak ayam jantan, Djermanovic et al. (2013) melaporkan bahwa obesitas pada ayam jantan mengurangi bobot testis relatif, konsentrasi testosteron serum dan jumlah total spermatozoa. Sementara itu, Fouad et al. (2020) mengatakan bahwa motilitas spermatozoa dan persentase spermatozoa hidup meningkat dengan pemberian pakan secara ad libitum dengan konsumsi 15,6 g PK/hari, meskipun volume semen berkurang. Ayam jantan yang diberi pakan dengan metode pembatasan pakan mengalami penurunan kesuburan dan libido. Hal tersebut terjadi terkait dengan implikasi anatomi yang berperan dalam penurunan kesuburan ayam jantan.

Zhang et al. (1999) menunjukkan bahwa volume semen dilaporkan lebih tinggi pada ayam jantan yang diberi pakan dengan kandungan PK $12 \%$ dibandingkan dengan $16 \%$ dari usia 28 hingga 36 minggu, meskipun konsentrasi spermatozoa tidak berbeda. Hocking (1989) menambahkan bahwa tidak ada perbedaan volume semen atau aktivitas metabolisme spermatozoa yang diamati pada ayam jantan yang diberi pakan dengan kandungan PK yang berbeda dari 80 hingga $400 \mathrm{~g} \mathrm{PK} / \mathrm{kg}$. Sementara itu, Revington et al. (1991) melaporkan bahwa tidak ada perbedaan volume semen, konsentrasi spermatozoa, jumlah spermatozoa total dari ayam jantan yang diberi pakan dengan kandungan 8 atau $12 \% \mathrm{PK}$. Wilson et al. (1988) mengatakan bahwa tidak ada efek pakan dengan kandungan PK 9, 12 atau 15\% PK terhadap volume semen, konsentrasi, jumlah spermatozoa yang di ejakulasikan atau aktivitas spermatogenik dari ayam jantan. Hocking, et al. (1997) mengatakan bahwa tidak ada perbedaan kesuburan antara ayam jantan yang diberi pakan dengan kandungan PK 12 atau 16\% PK. Duncan, et al. (1990) juga mengatakan bahwa tidak ada pengaruh dari efek tingkat protein pakan (11 atau 16\% PK) terhadap perilaku seksual. Namun, Hocking (1989) melaporkan bahwa proporsi ayam jantan yang memproduksi semen menurun dengan meningkatnya kandungan PK dalam pakan dari 8 menjadi $40 \%$. Ayam jantan yang diberi pakan dengan kandungan PK $11 \%$ menghasilkan telur fertil lebih tinggi dibandingkan dengan ayam yang diberi pakan dengan kandungan PK 16\% dan ayam jantan yang diberi pakan dengan kandungan PK 16\% memiliki konsentrasi semen yang lebih rendah dibandingkan dengan yang diberi pakan dengan kandungan PK 12\% (Hocking \& Bernard 1997).

Ghonim et al. (2010) mengatakan bahwa keseimbangan energi metabolis-protein dalam 
pakan memainkan peran penting dalam proses reproduksi ternak unggas jantan. Unggas jantan yang diberi pakan dengan kandungan energi metabolis atau PK tinggi menghasilkan volume ejakulasi lebih tinggi, motilitas spermatozoa juga meningkat oleh energi metabiolis yang tinggi, sedangkan kandungan PK tidak berpengaruh. Total spermatozoa abnormal berkurang dengan meningkatnya kandungan energi metabolis dan PK dalam pakan.

\section{PENGGUNAAN SUPLEMEN PAKAN DAN IMBUHAN PAKAN UNTUK MENINGKATKAN KUALITAS SEMEN AYAM}

Upaya peningkatan kualitas semen ayam jantan banyak dilaporkan dapat dilakukan dengan penggunaan suplemen pakan dan imbuhan pakan ke dalam pakan atau air minum ayam jantan.

\section{Suplementasi Antioksidan}

Adabi et al. (2011) melaporkan bahwa semen unggas mengandung tinggi asam lemak tak jenuh ganda (polyunsaturated fatty acids atau PUFAs). Long \& Kramer (2003) mengatakan bahwa PUFA telah dikaitkan dengan peningkatan radikal bebas dan peroksidasi lemak pada spermatozoa ayam. Ketika radikal bebas lebih tinggi dari mekanisme pertahanan antioksidan alami, maka spermatozoa akan rusak oleh peroksidasi lipid dan kemudian menurunkan fertilitas. Min et al. (2016) melaporkan bahwa spermatozoa dilindungi dari serangan radikal bebas dan peroksidasi lipid oleh berbagai antioksidan dan enzim yang ada dalam plasma semen. Oleh karena itu, antioksidan memiliki peran penting dalam reproduksi unggas.

Cerolini et al. (2006) mengatakan bahwa vitamin $\mathrm{E}$ adalah antioksidan alami yang mampu meningkatkan kualitas semen dan fertilitas. Biswas, et al. (2007) menambhakan bahwa vitamin E melindungi spermatozoa dari radikal bebas dan peroksidasi lipid, sehingga membantu mempertahankan kemampuan membuahi yang optimal. Laporan Tabatabaei et al. (2011) menunjukkan bahwa vitamin $\mathrm{E}$ merupakan antioksidan alami yang mampu meningkatkan kualitas semen dan kemampuan membuahi ayam ketika diberikan pada dosis sekitar 500 kali lebih besar dari tingkat kebutuhan NRC (15 IU/kg pakan). Banyak studi merekomendasikan suplementasi vitamin E dalam dosis $75-100 \mathrm{mg} / \mathrm{kg}$ pakan untuk menjaga fungsi fertilitas, baik pada unggas jantan maupun betina (Deivendran \& Ho Hong 2015). Surai (1999) mengatakan bahwa vitamin $\mathrm{E}$ telah banyak digunakan dalam pakan unggas untuk meningkat- kan produksi dan kinerja reproduksi unggas. Breque et al. (2003) menunjukkan bahwa suplementasi vitamin $\mathrm{E}$ dalam pakan efektif dalam menghambat peroksidasi lipid dari membran plasma spermatozoa ayam. Asrol \& Rashid (2017) melaporkan bahwa kualitas semen ayam jantan (motilitas, persentase viabilitas spermatozoa dan warna semen) meningkat dengan suplementasi 400 IU vitamin E ke dalam pakan selama 4 empat minggu.

Selain vitamin $\mathrm{E}$, vitamin $\mathrm{C}$ juga dapat digunakan sebagai sumber antioksidan dalam pakan dan air minum ayam jantan. Frei et al. (1989) mengatakan bahwa vitamin C dapat bertindak sebagai antioksidan penting yang menonaktifkan radikal bebas, sehingga mampu mencegah kerusakan lipida. Niki (1987) melaporkan bahwa vitamin $\mathrm{C}$ memiliki kemampuan meregenerasi potensi antioksidan vitamin $\mathrm{E}$ dengan menyumbangkan elektron askorbat ke radikal tokoferil. Triques et al. (2019) melaporkan bahwa penambahan pakan dengan sumber antioksidan (8 ppm canthaxanthin + lycopene 40 ppm +150 ppm vitamin C) meningkatkan kinerja reproduksi ayam jantan.

Antioksidan lainnya yang dapat digunakan untuk meningkatkan kualitas semen ayam adalah melatonin. Melatonin merupakan hormon lipofilik yang memiliki aktivitas antioksidan kuat dalam melawan aktivitas radikal bebas (Barrenetxe et al. 2004). Kozanoglu et al. (2006) melaporkan bahwa suplementasi $3 \mathrm{mg}$ melatonin per $\mathrm{kg}$ berat badan ayam jantan meningkatkan kualitas semen yang dihasilkan. Selain itu, bahan lain yang dilaporkan dapat meningkatkan kualitas semen ayam jantan adalah roti lebah. Fahim (2018) mengatakan bahwa suplementasi roti lebah hingga $1.5 \mathrm{~g} / \mathrm{kg}$ pakan pada pakan ayam jantan memiliki efek positif terhadap peningkatan kualitas semen, kemampuan membuahi dan daya tetas telur yang dihasilkan.

\section{Suplementasi Asam Amino}

Beberapa asam amino dilaporkan terkait dengan kinerja fungsi reproduksi. Wu et al. (2009) mengatakan bahwa di antara asam amino esensial, metabolisme L-Arginine melibatkan ginjal, usus, otot, hati dan testis. Funahashi (2002) melaporkan bahwa hasil percobaan in vitro menunjukkan bahwa kapasitansi spermatozoa babi jantan, mengalami peningkatan dengan suplementasi $L$ arginine. Hal ini terjadi, karena L-arginine merupakan satu-satunya donor nitrogen fisiologis pada reaksi produksi oksida nitrat (Hassanpour et al. 2010). Ren et al. (2015) mengatakan bahwa nitric oxide synthase merupakan enzim kunci yang 
mengendalikan produksi oksida nitrat dan meningkatkan karakteristik spermatozoa, ketika konsentrasi oksida nitrat meningkat. Hellstrom et al. (1994) menunjukkan bahwa nitrat oksida memiliki efek regulasi pada motilitas dan viabilitas spermatozoa, sehingga meningkatkan kemampuan membuahi dari spermatozoa. Stanislavov et al. (2004) melaporkan bahwa suplementasi $L$ arginine aspartat meningkatkan volume spermatozoa, konsentrasi dan motilitas. Sementara itu, Hassanpour et al. (2010) mengatakan bahwa $L$ arginine meningkatkan laju glikolisis dan menghasilkan adenosin trifosfat lebih tinggi dalam spermatozoa. Ahangar et al. (2017) melaporkan bahwa terjadi peningkatan berat testis dan berat relatif testis ayam jantan yang diberi suplementasi L-arginine. Ren et al. (2015) mengatakan bahwa L-arginine merangsang sekresi hormon pankreas dan hormon hipofisis anterior dengan demikian mengatur metabolisme protein, asam amino, glukosa dan asam lemak. Ahangar et al. (2017) menunjukkan bahwa suplementasi L-arginine pada dosis $1.35-3.22 \mathrm{~g} / \mathrm{kg}$ pada pakan ayam jantan memiliki efek positif pada sifat-sifat reproduksi, termasuk meningkatkan kualitas semen dan histologi testis ayam jantan.

Tapeh et al. (2016) mengatakan bahwa suplementasi $1200 \mathrm{mg}$ Asam Guanidino Asetat (GAA) per kg pakan memperbaiki kualitas semen pada ayam jantan. Tingkat kesuburan ayam jantan tua juga meningkat dengan suplementasi GAA ke dalam pakan. Dilger et al. (2013) mengatakan bahwa Asam Guanidino Asetat (GAA) disintesis dari glisin dan arginin oleh l-arginine:glycine amidinotransferase (AGAT) di ginjal dan hati ternak unggas. Selanjutnya, guanidinoacetate $N$ methyltransferase (GAMT) mengkatalisasi pembentukan kreatin melalui transfer gugus metil dari S-adenosylmethionine ke GAA (Walker, 1979).

Bahan lain yang meningkatkan kualitas semen adalah kreatin. Kreatin dibentuk dari tiga asam amino, yaitu methionin, arginin dan glisin. Schmidt (2004) mengatakan bahwa kreatin dilaporkan memiliki peran penting dalam saluran reproduksi jantan. Kreatin terkait dengan fungsi kinerja reproduksi ayam jantan, karena berperan dalam produksi energi yang dibutuhkan dalam produksi spermatozoa. Adenosine triphosphate (ATP) merupakan bahan bakar untuk motilitas spermatozoa yang kandungannya dalam semen dan spermatozoa digunakan untuk meningkatkan kesuburan jantan (Vigue, 1992). Creatine phosphate dapat mengubah adenosine diphosphate (ADP) menjadi ATP dan akibatnya mendukung motilitas spermatozoa (Vigue et al. 1992). Sumber bahan lain yang dilaporkan dapat meningkatkan kualitas semen adalah selenomethionine. Hanafy et al. (2009) melaporkan bahwa suplementasi 0,3 $\mathrm{mg} / \mathrm{kg}$ selenomethionine ke dalam pakan ayam jantan mampu meningkatkan kualitas semen, fertiitas dan daya tetas telur.

\section{Suplementasi Senyawa Bioaktif Tanaman}

Surai et al. (1998) menyatakan bahwa semen kaya akan asam lemak tak jenuh ganda (polyunsaturated fatty acids atau PUFA) yang diperlukan untuk mempertahankan sifat membran spermatozoa, tetapi sangat rentan terhadap peroksidasi. Sistem pertahanan yang mencakup antioksidan yang bersumber dari bioaktif tanaman, seperti flavonoid dan karotenoid dapat mengurangi kerentanan semen terhadap oksidasi, yang berakibat meningkatkan fertilitas. Clement et al. (2012) mengatakan bahwa imbuhan pakan dari tanaman kaya akan senyawa tertentu yang memiliki aktivitas antioksidan. Christaki (2012) melaporkan bahwa tanaman memiliki banyak senyawa bioaktif, khususnya polifenol, yang dikenal memiliki kapasitas sebagai antioksidan.

Beberapa jenis tanaman dilaporkan memiliki aktivitas antioksidan yang bermanfaat positif dalam meningkatkan kualitas semen ayam jantan. Ekstrak tanaman atau buah-buahan yang kaya senyawa alami, seperti likopen, L-karnitin, macaenes dan ekstrak sage telah terbukti meningkatkan kualitas semen pada ternak unggas (Clément et al. 2012; Ommati et al. 2013). Landete (2011) melaporkan bahwa asam ellagic adalah salah satu senyawa alami yang kaya polifenol terkondensasi memiliki potensi sebagai antioksidan dan banyak ditemukan pada buah, sayuran dan sereal. Ekstrak etanol dari delima juga telah terbukti melindungi atau mencegah kerusakan sel testis dan kerusakan spermatozoal oleh berbagai senyawa toksik pada pengujian di laboratorium (Sönmez et al. 2011). Saeid et al. (2011) melaporkan bahwa suplementasi ekstrak jahe (dengan ekstraksi air) pada pakan ayam jantan meningkatkan konsentrasi spermatozoa dan penurunan spermatozoa abnormal. Akhlaghi et al. (2014) melaporkan bahwa penggunaan $15 \mathrm{~g} / \mathrm{kg}$ pakan tepung jahe ke dalam pakan ayam jantan meningkatkan kualitas semen ayam jantan.

Sumber tanaman lain yang dilaporkan memiliki aktivitas antioksidan tinggi adalah biji wijen. Dimitrios (2006) mengatakan bahwa biji wijen sangat tahan terhadap kerusakan oksidatif dan merupakan biji minyak tertua yang digunakan untuk meningkatkan fertilitas. Aktivitas 
antioksidan yang kuat dari wijen adalah tingginya tingkat komponen bioaktif, yaitu lignan sesamin dan sesamolin, tembaga dan kalsium, fosfor, besi, magnesium, mangan, seng dan vitamin B1 (Pathak et al. 2014; Gharby et al. 2017). Asam lemak tak jenuh utama dari biji wijen adalah asam linoleat (37-47\%), asam oleat (35-43\%), palmitat $(9-11 \%)$ dan asam stearat $(5-10 \%)$. Selain itu, wijen juga mengandung lignan lain termasuk sesaminol, sesangolin dan 2-episalatin yang memiliki sifat antioksidan (Dimitrios, 2006; Gharby et al. 2017). Xuan, et al. (2019) melaporkan bahwa penggunaan 7\% biji wijen dalam pakan ayam jantan meningkatkan kualitas semen. Beberapa laporan lainnya menunjukkan bahwa kualitas semen ayam dapat ditingkatkan melalui suplementasi ekstrak sage, tomat kering, apel kering, tanaman mint (Labiates), rosemary (Rosmarinus officinalis), sage (Salvia officinalis) dan S. khuzistanica (Haeri et al. 2006; Saemi et al. 2012; Ommati et al. 2013).

Perbaikan kualitas semen juga dapat dilakukan dengan penambahan sumber karotenoid ke dalam pakan atau air minum ayam jantan. Karotenoid adalah kelompok antioksidan alami yang banyak terdapat pada buah-buahan dan sayuran merah (Lindshield et al. 2007; Frusciante et al. 2007). Likopen merupakan hidrokarbon karotenoid merah cerah, umumnya ditemukan pada buah dan sayuran, beberapa buah dan sayuran yang mengandung likopen, diantaranya pepaya, wortel, dan semangka. Suplementasi likopen pada pakan bermanfaat positif terhadap kualitas semen dan spermatozoa ayam jantan (Turk et al. 2007). Laporan Mangiagalli et al. (2010) menunjukkan bahwa penambahan lycopene dalam air minum ayam jantan pada dosis $0,5 \mathrm{~g} / \mathrm{L}$ meningkatkan produksi dan kualitas semen ayam jantan. Kunyit (Curcuma longa) merupakan sumber utama senyawa fenolik (curcuminoids) (Maheshwari et al. 2006). Curcumin, merupakan komponen bioaktif utama kunyit, adalah antioksidan alami dan dapat bertindak sebagai agen anti-inflamasi, anti-apoptotik, anti-toksik dan antikanker (Chattopadhyay et al. 2004). Yan et al. (2017) melaporkan bahwa suplementasi tepung kunyit dalam pakan ayam jantan meningkatkan kualitas semen. Kazemizadeh et al. (2019) melaporkan bahwa suplementasi curcumin pada dosis $30 \mathrm{mg} / \mathrm{kg}$ dalam pakan ayam jantan meningkatkan kualitas semen.

Hassanpour et al. (2011) mencatat bahwa tanaman dengan genus Allium adalah tanaman yang kaya berbagai metabolit sekunder, seperti flavonoid, tanin, trepenoid, alkaloid dan lainnya. Tanaman spesies Allium yang dapat dikonsumsi, yaitu bawang putih (Allium sativum L.) dan bawang merah (Allium cepa L.), telah lama digunakan sebagai bahan makanan dan obat-obatan (Kim et al. 2011). Suplementasi bawang merah dan bawang putih dilaporkan memiliki dampak positif terhadap peningkatan produksi ternak. Disamping itu juga dilaporkan bahwa sifat antioksidatif dari jus bawang merah terbukti memiliki efek positif pada kesehatan spermatozoa dan spermatogenesis pada hewan uji (tikus dan kelinci) (Khaki et al. 2012; Alagawany et al. 2015). Okoro et al. (2016) melaporkan bahwa suplementasi bawang merah dan bawang putih, pada masingmasing dosis $5 \mathrm{~g} / \mathrm{kg}$ bahan kering pakan mampu meningkatkan kualitas semen ayam jantan.

\section{Suplementasi Mikromineral}

Mikromineral sebagai bagian dari banyak enzim diperlukan untuk reaksi biokimia normal. Barber et al. (2005) melaporkan bahwa mikromineral $\mathrm{Zn}, \mathrm{Mn}, \mathrm{Cu}$ dan Se dilaporkan meningkatkan spermatogenesis dan meningkatkan kualitas semen pada ternak ayam jantan. Graupner et al. (2015) mengatakan bahwa defisiensi Selenium (Se) dapat memperlambat perkembangan testis dan epidydymis, menurunkan kepadatan spermatozoa dalam semen dan meningkatkan produksi sel spermatozoa abnormal. Selenium juga dilaporkan merupakan elemen penting untuk nutrisi unggas yang memainkan peran penting dalam kinerja produksi dan reproduksi ternak unggas, baik jantan maupun betina (Surai \& Fisinin, 2014). Suplementasi Se dilaporkan memperbaiki kierja reproduksi ayam jantan. Edens dan Sefton (2009) melaporkan bahwa suplementasi Se sangat terkait dengan morfologi spermatozoa dan kualitas semen (Ebeid, 2009). Sementara itu, Surai \& Taylor-Pickard (2008) mengatakan bahwa suplementasi $0,30 \mathrm{ppm} / \mathrm{kg}$ Se organik dalam pakan ayam jantan selama 33 minggu produksi dikaitkan dengan peningkatan fertilitas $(0,4-4,5 \%)$ dan peningkatan daya tetas (1-6\%). Emamverdi et al. (2019) melaporkan bahwa suplementasi Se organik pada dosis $0,45 \mathrm{mg} / \mathrm{kg}$ ke dalam pakan ayam umur tua menyebabkan peningkatan kinerja reproduksi.

Taniguchi et al. (2007) mengatakan bahwa $\mathrm{Zn}$ sangat terkait dengan sifat anti bakteri dari semen. Selain itu, $\mathrm{Zn}$ berperan dalam stabilisasi sel sperma dan mencegah degradasi membran spermatozoa. Awal pengembangan prostata membutuhkan kadar $\mathrm{Zn}$ yang tinggi, dimana kekurangan $\mathrm{Zn}$ akan menunda pengembangan karakteristik seksual sekunder dan mengurangi kadar testosteron (Kothari \& Chaudhari, 2016). 
Suchý et al. (1998) melaporkan bahwa suplementasi $\mathrm{Zn}$ meningkatkan pematangan gonad pada ayam pejantan. Shanmugam et al. (2014) menemukan bahwa suplementasi Zn organik pada dosis $100 \mathrm{ppm} / \mathrm{kg}$ pakan meningkatkan metabolisme spermatozoa ayam. Amem \& Aldaraji (2011) menunjukkan bahwa suplementasi Zn pada dosis $50-100 \mathrm{mg} / \mathrm{kg}$ pada pakan meningkatkan kualitas semen ayam. Moce et al. (2000) melaporkan bahwa volume ejakulasi semen pada hewan uji (kelinci) meningkat seiring dengan suplementasi $\mathrm{Zn}$ pada dosis $35-100 \mathrm{ppm} / \mathrm{kg}$ pakan. Shanmugam et al. (2015) mengatakan bahwa kombinasi suplementasi $100 \mathrm{mg} \mathrm{Zn} / \mathrm{kg}$ dan 0,35 $\mathrm{mg} \mathrm{Se} / \mathrm{kg}$ pada pakan ayam jantan meningkatkan kualitas semen ayam.

Tembaga atau $\mathrm{Cu}$ diperlukan untuk menjaga stabilitas luteotropic hormone (LH) dan folliclestimulating hormone (FSH) dalam serum. Selain itu, $\mathrm{Cu}$ juga dapat meningkatkan kapasitas prostata untuk mengeluarkan testosteron dengan meningkatkan kapasitas pengikatan prostaglandin E2 (PGE2) terhadap reseptornya di prostata (Wang et al. 2014). Prostaglandin E2 dapat mengatur sintesis $\mathrm{LH}$ melalui $\mathrm{Cu}$, meningkatkan kadar serum LH, dengan demikian menginduksi sekresi testosteron untuk menginisiasi diferensiasi dan pematangan sel spermatozoa (Sakumoto et al. 2014). Kandungan mangan (Mn) dalam pakan juga dilaporkan mempengaruhi perkembangan testis, spermatogenesis, pertumbuhan dan pengembangan sel spermatozoa (Gu \& Hecht, 1996).

\section{Suplementasi Probiotik}

Probiotik adalah mikroorganisme hidup yang meningkatkan kesehatan hewan ketika ditambahkan ke dalam pakan. Probiotik bertindak menyeimbangkan flora usus, mempengaruhi vili usus dan meningkatkan pencernaan dan penyerapan nutrisi. Suplementasi probiotik dalam pakan ayam telah terbukti meningkatkan pertumbuhan dan produktifitas, kecernaan nutrisi, modulasi mikroflora usus, menghambat pertumbuhan bakteri patogen, memperbaiki imunomodulasi dan imunitas mukosa usus serta berfungsi sebagai antioksidan (McDaniel et al., 1991; Khan et al., 2012). Probiotik menggunakan berbagai mikroorganisme, diantaranya genus Lactococcus, Lactobacillus, Bacillus, Bifidobacterium, Enterococcus, Streptococcus dan banyak genus ragi. Hasil penelitian Inatomi dan Otomaru (2018) menunjukkan bahwa suplementasi $0,2 \%$ probiotik komersial (produksi TOA
Pharmaceutical Co. Ltd., Tokyo, Jepang) yang mengandung Bacillus amyloliquefaciens TOA5001 pada konsentrasu $1 \times 10^{8}$ mampu meningkatkan kualitas semen ayam.

\section{Suplementasi sumber asam lemak}

Hudson \& Wilson (2003) mengatakan bahwa manipulasi asam lemak dalam pakan telah disarankan sebagai salah satu metode untuk meningkatkan kualitas semen ayam. Lemak merupakan komponen semen unggas yang terlibat dalam aktivitas biologis spermatozoa. Bongalhardo et al. (2009) mengatakan bahwa sumber lemak atau asam lemak dari pakan mempengaruhi komposisi dan fungsi spermatozoa ayam. Beberapa laporan menunjukkan bahwa spermatozoa dari spesies unggas menunjukkan konsentrasi yang sangat rendah pada asam docosahexaenoic dalam fosfolipidnya. Sebaliknya, komponen lemak utama dari spermatozoa unggas adalah arachidonic (20: 4n-6) dan asam docosatetraenoic (22: 4n-6) (Kelso et al., 1996). Spermatozoa unggas ditandai oleh tinggi jumlah C20_22 polyunsaturate dari seri n-6. Hal tersebut terjadi, karena produksi unggas komersial saat ini bergantung pada pakan komersial yang umumnya mengandung kelebihan besar asam lemak n-6 (terutama asam linoleat (18: 2n-6)) di atas asam lemak n-3 (Noble, 1986).

Asam lemak 22: 6n-3 hadir dalam spermatozoa dan melakukan fungsi penting dalam mempromosikan kesuburan optimal. Pengurangan jumlah asam lemak lemak 22: 6n-3 dalam spermatozoa terkait dengan gangguan jumlah spermatozoa, motilitas dan fertilitas (Nissan dan Kreysel, 1983). Kelso et al. (1997) melaporkan bahwa suplementasi pakan ayam jantan dengan $\alpha$ asam linolenat 18: 3n-3 yang bersumber dari minyak biji rami dengan kandungan lemak kasar 9\% dalam pakan berhasil meningkatkan kemampuan pembuahan spermatozoa. Olubowale, et al. (2014) melaporkan bahwa penggunaan 1,5\% minyak ikan $+1.5 \%$ minyak biji rami atau $3 \%$ minyak bunga matahari dapat digunakan dalam menjaga motilitas spermatozoa. Demikian pula, fertilitas dan daya tetas telur tetas yang tinggi dicapai pada unggas tua (umur $\geq 69$ minggu) dengan memberi pakan yang mengandung sumber asam lemak n-3 (minyak biji rami dan minyak ikan) atau tambahan asam lemak n-9 (minyak bunga matahari) sebagai sumber lemak. Khatibjoo, et al. (2011) mengatakan bahwa penggunaan sumber minyak mengandung omega3 meningkatkan kualitas semen ayam jantan. 


\section{KESIMPULAN}

Kualitas semen ayam jantan sangat dipengaruhi oleh faktor pakan. Pengaturan kandungan gizi pakan yang diberikan, terutama pengaturan imbangan kandungan energi metabolisprotein dalam pakan ayam jantan sangat penting untuk dilakukan untuk menjaga berat badan ayam jantan agar tidak terjadi kelebihan dan kekurangan berat badan. Berat badan sangat mempengaruhi kualitas semen ayam yang dihasilkan. Upaya pendekatan pakan lainnya untuk meningkatkan kualitas semen ayam adalah suplementasi suplemen pakan dan imbuhan pakan. Jenis suplementasi yang dapat dilakukan, yaitu suplementasi bahan sumber antioksidan, asam amino, mikromineral, bahan mengandung bioaktif tanaman, bahan sumber asam lemak, dan probiotik.

\section{DAFTAR PUSTAKA}

Adabi, G. S. H., R.G. Cooper, M.A. Kamali, \& A. Hajbabaei. 2011. The influence of inclusions of vitamin $\mathrm{E}$ and corn oil on semen traits of Japanese quail (Coturnix coturnix japonica). Anim. Reprod. Sci. 123 (1-2): 119-125.

Adamu, J., A. Dauda, \& H. Abbaya. 2019. Effect of genotype and seasons on semen characteristics of three indigenous cock types in the semi arid zone of Nigeria. Int $\mathbf{J}$ Avian and Wildlife Biol 4(3):90-94.

Ahangar, M., S. Asadzadeh, V. Rezaeipour, \& A.Z. Shahneh. 2017. Effects of L-Arginine supplementation on semen quality, testosterone concentration and testes histological parameters of Ross 308 breeder roosters. Asian Pacific Journal of Reproduction. 6 (3):133-135.

Akhlaghi, A., Y.J. Ahangari, B. Navidshad, Z. Ansari Pirsaraei, M. Zhandi, H. Deldar, M.R. Rezvani, M. Dadpasand, S.R. Hashemi, R. Poureslami, \& E.D. Peebles. 2014. Improvements in semen quality, sperm fatty acids, and reproductive performance in aged Cobb 500 breeder roosters fed diets containing dried ginger rhizomes (Zingiber officinale). Poult. Sci 93:1236-1243.

Akingbemi. B.T. 2005. Estrogen regulation of testicular function. Reprod Biol Endoc.3:113.

Alagawany, M., E.A. Ashour, \& F.M. Reda. 2015. Effect of dietary supplementation of garlic
(Allium sativum) and turmeric (Curcuma longa) on growth performance, carcass traits, blood profile and oxidative status in growing rabbits. Ann Anim Sc. 16(2):489505.

Al-Daraji, H.J. \& M.H. Amen. 2012. Effect of the supplementation of the broiler breeder males ration with zinc on histological traits of testes. Intl. J Appl Poult Res 1(1):10-14.

Almahdi, A.B., Y.S. Ondho, \& Sutopo. 2014. Comparative studies of semen quality on different breed of chicken in poultry breeding center Temanggung-Central Java. International Refereed Journal of Engineering and Science (IRJES) 3(2):94103.

Amem, M.H.M. \& H.J. Al-Daraji. 2011. Effect of dietary zinc on semen quality of cobb 500 broiler breeder males. Intl. J Poult Sci 10 (6):477-482.

Ansari, M., M. Zhandi, H. Kohram, M. Zaghari, M. Sadeghi, M. Gholami, H. Deldar, M. M. Di fiore, \& A.P. Benson. 2018. Aspartate amends reproductive performance of aged roosters by changing gene expression and testicular histology. Reprod Fertil Dev 30:1038-1048.

Ardhani, F., I.M.U. Raharja, B.M. Boangmanalu, \& J. Handoko. 2018. Karakteristik morfologik dan morfometrik spermatozoa ayam nunukan. Jurnal Peternakan 15(2):62-67.

Asrol, M.K. \& A. Rashid. 2017. Effect of vitamin E supplementation on semen quantity and quality of Local Kampong roosters. Mal $\mathbf{J}$ Anim Sci 20(1):37-43.

Barber, S.J., H.M. Parker, \& C.D. McDaniel. 2005. Broiler breeder semen quality as affected by trace minerals in vitro. Poult Sci 84:100105.

Bearden, H.J., J.W. Fuquay, \& S.T. Willard. 2004. Applied Animal Reproduction. 6th Edition. Pearson Education, Inc. New Jersey. pp.109-27.

Biswas, A., J. Mohan, K.V.H. Sastry, \& J.S. Tyagi. 2007. Effect of dietary vitamin $E$ on the cloacal gland, foam and semen characteristics of male Japanese quail. Theriogenology 67(2):259-263.

Bongalhardo, D.C., S. Leeson, \& M.M. Buhr. 2009. Dietary lipids differentially affect 
membranes from different areas of rooster sperm. Poult Sci 88:1060-1069.

Brière, S., J.P. Brillard, M. Panheleux, \& P. Froment. 2011. Alimentation, fertilité et bien-être des oiseaux re- producteurs domestiques: Des liens complexes. INRA Productions Animales 24:171-180.

Cerolini, S., L. Zaniboni, A. Maldjian, \& T. Gliozzi. 2006. Effect of docosahexaenoic acid and $\alpha$-tocopherol enrichment in chicken sperm on semen quality, sperm lipid composition and susceptibility to peroxidation. Theriogenology 66(4):877886.

Chattopadhyay, I., K. Biswas, U. Bandyopadhyay, \& R.K. Banerjee. 2004. Turmeric and curcumin: biological actions and medicinal applications. Current science 87:44-53.

Chen, S.E., J.P. McMurtry, \& R.L. Walzem. 2006. Overfeeding-induced ovarian dysfunction in broiler breeder hens is associated with lipotoxicity. Poult Sci 85:70-81.

Clément, C., U. Witschi, \& M. Kreuzer. 2012. The potential influence of plantbased feed supplements on sperm quantity and quality in livestock: A review. Anim Reprod Sci 132:1-10.

Danang, D. R., N. Isnaini, \& P. Trisunuwati. 2012. Pengaruh lama simpan semen terhadap kualitas spermatozoa ayam kampung dalam pengencer ringer's pada suhu $40^{\circ} \mathrm{C}$. J Ternak Tropika 13(1):47-57.

Dasrul, M.H. \& C.N. Thasmi. 2017. Pengaruh frekuensi penampungan semen terhadap kualitas spermatozoa pada ayam bangkok. JIMVET 1(1):46-53.

Deivendran, R. \& Y. Ho Hong. 2015. .Effects of Dietary Vitamin E on Fertility Functions in Poultry Species. Intl J Mol Sci 16:99109921.

Dilger, N.R., K. Bryant-Angeloni, R.L. Payne, A. Lemme, \& C.M. Parsons. 2013. Dietary guanidinoacetic acid is an efficacious replacement for arginine for young chicks. Poult Sci 92:171-7.

Dimitrous, B. 2006. Sources of natural phenolic antioxidants. Trends in Food Science and Technology 17:505-512.

Djermanovic, V., S. Mitrovic, \& V. Djekic. 2013. Rooster body weight influence on the reproductive performance of the broiler parents. Biotechnology in Animal Husbandry 29 (1):83-91.

Duncan, I.J.H., P.M. Hocking, \& E. Seawright. 1990. Sexual behaviour and fertility in broiler breeder domestic fowl. Appl Anim Behav Sci 26:201-213.

Ebeid, T.A. 2009. Organic selenium enhances the antioxidative status and quality of cockerel semen under high ambient temperature. British Poult Sci 50:641-47.

Edens, F.W. \& A.E. Sefton. 2009. Sel-Plex ${ }^{\circledR}$ improves spermatozoa morphology in broiler breeder males. Intl. J Poult Sci 8:853-61.

El-Dlebshany, E.A. 2008. The relationship between age at sexual maturity and some productive traits in local chickens strain. Egyptian Poult Sci 28:1253-1263.

Emamverdi, M., A. Zare-Shahneh, M. Zhandi, M. Zaghari, D. Minai-Tehrani, \& M. KhodaeiMotlagh. 2019. An improvement in productive and reproductive performance of aged broiler breeder hens by dietary supplementation of organic selenium. Theriogenology 126:279-285.

Envan, E., A.R. Alimon, A.Q. Sazili, \& H. Yaakub. 2008. Effect of Varying Levels of Leucine and Energy on Performance and Carcass C haracteristics of Broiler Ghickens. International Journal of Poultry Science 7(7):696-699.

Fahim, H.N. 2018. Semen quality and fertilizing ability of sinai cocks fed bee bread as a natural supplement to the diet. J Anim Poult Prod 9(2):77-83.

Fouad, A.M., H. K. El-Senousey, D. Ruan, W. Xia, W. Chen, S. Wang, \& C. Zheng. 2020. Nutritional modulation of fertility in male poultry. https://www.sciencedirect.com/ science/article/pii/S0032579120305149 [19 September 2020].

Fre, I.B., L. England, \& B. N. Ames. 1989: Ascorbate is an outstanding antioxidant in human blood plasma. Proc Nat Academy Sci 86: 6377-638.

Frusciante, L., P. Carli, M.R. Ercolano, R. Pernice, A. Di Matteo, V. Fogliano, \& N. Pellegrini. 2007. Antioxidant nutritional quality of 
tomato. Molec Nutrition and Food Research 51(5):609-617.

Funahashi. H. 2002. Induction of capacitation and the acrosome reaction of boar spermatozoa by L-arginine and nitric oxide synthesis associated with the anion transport system. Reproduction 124(6):857-864.

Garner, D.L., \& E.S.E. Hafez. 2008. Spermatozoa and seminal plasma. In. Reproduction in Farm Animals. $7^{\text {th }}$ Edition. Lippincott Williams and Wilkins: Maryland. USA.

Gharby, S., H. Harhar, Z. Bouzoubaa, A. Asdadi A., A. El Yadini, \& Z. Charrouf. 2017. Chemical characterization and oxidative stability of seeds and oil of sesame grown in Morocco. J Saudi Soc Agric Sci 16:105111.

Ghonim, A.I.A., A.L. Awad, K. Elkloub, \& M.E. Moustafa. 2010. Effect of feeding different levels of energy and crude protein on semen quality and fertility of Domyati ducks. Egypt Poult Sci 30 (II):583-600.

Graupner, A., C. Instanes, J.M. Andersen, A. Brandt-Kjelsen, S.D. Dertinger, \& B. Salbu. 2015. Genotoxic effects of two-generational selenium deficiency in mouse somatic and testicular cells. Mutagenesis 30(2):217-225.

Gu, W. \& N.B. Hecht. 1996. Developmental expression of glutathione peroxidase, catalase, and manganese superoxide dismutase mRNAs during spermatogenesis in the mouse. J Androl 17:256-62.

Guo, Z., B. Zhou, Y. Wan, J. Zhou, D. Shi, Z. Geng, X. Chen, \& R. Jiang. 2016. Effects of Caponization on Expression of Gonadotropin-Releasing Hormone-I and Gonadotropin Subunits Genes in Roosters. J Poult Sci 53:58-62.

Haeri, S., B. Minaie, G. Amin, S. Nikfar, R. Khorasani, H. Esmaily, A. Salehnia, \& M. Abdollahi. 2006. Effect of Satureja khuzestanica essential oil on male rat fertility. Fitoterapia 77:495-499.

Hanafy, M.M., A.M.H. El-Sheik, \& E.A. Abdalla. 2009. The effect of organic selenium supplementation on productive and physiological performance in local strain of chicken. Egyptian Poult Sci Assoc 29(4):1061-1084.
Hassanpour, H., M. Teshfam, A. Karimi Goodarzi, P. Tajik, \& P. Mirshokraei. 2010. In vitro effects of l-arginine on motion parameters in ram epididymal sperm. Comp Clin Pathol 19(4):351-355.

Hassanpour, S., M. Sadaghian, N. MaheriSis, B. Eshratkhah, \& M. ChaichiSemsari. 2011. Effect of condensed tannin on controlling faecal protein excretion in nematodeinfected sheep: in vivo study. J American Sci 7:896-900.

Hellstrom, W.J.G., M. Bell, R. Wang, \& S.C. Sikka. 1994. Effect of sodium nitroprusside on sperm motility, viability and lipid peroxidation. Fertil Steril 61(6):1117-1122.

Hocking, P.M., \& R. Bernard. 1997. Effects of male body weight, strain and dietary protein content on fertility and musculo-skeletal disease in naturally mated broiler breeder males. British Poult Sci 38:29-37.

Hocking, P.M., \& S.R.I. Duff. 1989. Musculoskeletal lesions in adult male broiler breeder fowls and their relationships with body weight and fertility at 60 weeks of age. British Poult Sci 30:777-784.

Hoesni, F. 2016. Pengaruh penggunaan tris dalam pengencer susu skim terhadap resistensi spermatozoa sapi simmental pasca pembekuan fachroerrozi hoesni. Jurnal Ilmu-Ilmu Peternakan 19(2):77-82.

Hudson, B.P., \& J.L. Wilson. 2003. Effects of dietary menhaden oil on fertility and sperm quality of broiler breeder males. J Appl Poult Res 12:341-347.

Inatomi, T.K. \& Otomaru. 2018. Effect of dietary probiotics on the semen traits and antioxidative activity of male broiler breeders. Scientific Reports Volumen 8, Article number:5874. DOI: 10.1038/s41598018-24345-8

Iswati., N. Isnaini., \& T. Susilawati. 2017. Fertilitas spermatozoa ayam buras dengan penambahan antioksidan glutathione dalam pengencer ringes's selama simpan dingin. Jurnal ilmu-ilmu peternakan. 27(1):107-115.

Kazemizadeh, A., A.Z. Shahneh, S. Zeinoaldini, A.R. Yousefi, H.M. Yeganeh, Z.A. Pirsaraei, \& A. Akhlaghi. 2019. Effects of dietary Curcumin supplementation on seminal quality indices and fertility rate in broiler breeder roosters. Journal British 
Poultry Science 60(3). DOI: 10.1080/ 00071668.2019.1571165

Kelso, K.A., S. Cerolini, B.K. Speake, L.G. Cavalchini, \& R.C. Noble. 1997. Effects of dietary supplementation with $\alpha$-linolenic acid on the phospholipid fatty acid composition and quality of spermatozoa in cockerel from 24 to 72 weeks of age. J Reprod Fertil 110:53-59.

Kelso, K.A, S. Cerolini, R.C. Noble, N.H.C. Sparks, \& B.K. Speake. 1996. Lipid and antioxidant changes in semen of broiler fowl from 25 to 60 weeks of age J Reprod Fertil 106:201-206.

Khaki, A., A. Farnam, A. Davatgarbadil, \& H. Nikniaz. 2012. Treatment effects of onion (Allium cepa) and ginger (Zingiber officinale) on sexual behavior of rat after inducing an antiepileptic drug (lamotrigine). Balkan Med J 29:236-242.

Khan, R.U., Z. Rahman, I. Javed, \& F. Muhammad. 2012. Effects of vitamins, probiotics, and protein level on semen traits and some seminal plasma macro- and microminerals of male broiler breeders after zinc-induced molting. Biol Trace Elem Res 148:44-52.

Khatibjoo, A., H. Kermanshahi, R. Alimon, A. Golian, \& M. Zaghari. 2011. Effect of omega6: omega3 fatty acid ratios on semen quality of Malaysian village roosters. Global Vet. 6 (2):213-219.

Kim, S., S. Jo, Y. Kwon, \& J. Hwong. 2011. Effect of onion (Allium cepa) extract administration on intestinal glucosidases activities and spikes in postprandid blood glucose levels in SD rats model. Intl J Molec Sci 58: 213-220.

Kirk, S., G.C. Emmans, R. McDonald, \& D. Arnist. 1980. Factors affecting hatchability of eggs from broiler breeders. British Poult Sci 21:37-43.

Kothari, R.P. \& A.R. Chaudhari. 2016. Zinc levels in seminal fluid in infertile males and its relation with serum free testosterone. $\mathbf{J}$ Clinic Diag Res 10(5):CC05-8.

Landete, J.M. 2011. Ellagitannins, ellagic acid and their derived metabolites: A review about source, metabolism, functions and health. Food Res Intl 44:1150-1160.
Leeson, S. \& J.D. Summers. 2009. Broiler breeder production. Nottingham University Press. England.

Lindshield, B.L., K. Canene-Adams, \& J.W. Erdman. 2007. Lycopenoids: Are lycopene metabolites bioactive? Archives Biochem Biophys 458:136-140.

Long, J. \& M. Kramer. 2003. Effect of vitamin E on lipid peroxidation and fertility after artificial insemination with liquid-stored turkey semen. Poult Sci 82(11):1802-1807.

Lüpold, S., J. Wistbutba, S.O. Damm, W.J. Rivers, \& R.T. Birkhead. 2011. Sperm competition leads to func- tional adaptations in avian testes to maximize sperm quan- tity and quality. Reprod 141:595-605.

Maheshwari, R.K., A.K. Singh, J. Gaddipati, \& R.C. Srimal. 2006. Multiple biological activities of curcumin: a short review. Life Science 78:2081-7.

Mahmoodpour, H., S.Vahdatpour, M. Jafargholipour, \& T. Vahdatpou. 2017. Effects of low-protein diets supplemented with antioxidants on histopathology of testis and testosterone and performance of male Japanese quail (Coturnix coturnix japonica). R Bras Zootec 46 (2):123129.

Mangiagalli, M.G, P.A. Martino, T. Smajlovic, L. Guidobono Cavalchini, \& S.P. Marelli. 2010. Effect of lycopene on semen quality, fertility and native immunity of broiler breeder. British Poult Sci 51(1):152-157.

Mangiagalli, M.G., S.P. Marelli, \& L.G. Cavalchini. 2007. Effect of lycopene on fowl sperm characteristics during in vitro storage. Archive Geflügelkunde 71:25-29.

Marie, Y.A., M.A. Ibrahim, M.A. Mahmoud, \& H.A. Abou- Khashaba. 2009. Influence of nutrient density on productive and reproductive performance of some local laying hen strains. Egyptian Poult Sci 29: 527-564.

McDaniel, G.R. \& T. Sefton. 1991. Effect of yeast culture (Yeasacc1026) supplementation on broiler breeders. Poult Sci 70(1):172 (Abstr.)

McGovern, R.H. 2002. Reproduction in male broiler breeders. https://getd.libs.uga.edu/ pdfs/mcgovern_ruth_h_200208_phd.pdf.

[19 September 2020]. 
Min, Y., T. Sun, Z. Niu, \& F. Liu. 2016. Vitamin $\mathrm{C}$ and vitamin $\mathrm{E}$ supplementation alleviates oxidative stress induced by dexamethasone and improves fertility of breeder roosters. Anim Reprod Sci 171:1-6.

Moce, E., M. Arouca, R. Lavara, \& J.J. Pascual. 2000. Effect of dietary zinc and vitamin supplementation on semen characteristics of high growth rate males during summer season. Effect of dietary zinc and vitamin supplementation on semen characteristics of high growth rate males during summer season. Proceedings 7th World Rabbit Congress, Valencia, A: 203-209.

Moyle, J.R., D. E. Yoho, S. M. Whipple, A. M. Donoghue, \& R. K. Bramwell. 2012. Sperm production and testicular development of broiler breeder males reared on shortened growth cycles. J Appl Poult Res 21:88-94.

Niki, E. 1987: Interaction of ascorbate and alphatocopherol. Ann NY Acad Sei 498:186199.

Nissen, H.P., H.W. Kreysel, \& C. Schirren. 1981. Composition of the lipid-bound fatty acids of human semen in relation to its fertility values. Andrologia 13:444-451.

Noble, R.C. 1986. Egg lipids. In Egg Quality: Current Patterns and Recent Advances. Edited by Wills R.G. and C.G. Belyavin. Butterworths. London. 159-177.

Okoro, V.M.O., C. A Mbajiorgu, \& E.F. Mbajiorgu. 2016. .Semen quality characteristics of Koekoek breeder cocks influenced by supplemental inclusion levels of onion and garlic mixture at 35-41 weeks of age. R Bras Zootec 45 (8):433-440.

Olubowale, O.S., F. H. de Witt, J.P.C. Greyling, A. Hugo, A.M. Jooste, \& M.B. Raito. 2014. The effect of dietary lipid sources on layer fertility and hatchability South African J Anim Sci 44 (5):S45-S50.

Ommati, M.M., M.J. Zamiri. A. Akhlaghi, H. Atashi, M.R. Jafarzadeh, M.R. Rezvani, \& F. Saemi. 2013. Seminal characteristics, sperm fatty acids, and blood biochemical attributes in breeder roosters orally administered with sage (Salvia officinalis) extract. Anim Prod Sci 53:548554.

Pathak, N., A.K. Rai, R. Kumari, \& K.V. Bhat. 2014. Value addition in sesame: A perspective on bioactive components for enhancing utility and profitability. Pharmac $\operatorname{Rev} 8(16): 147-155$.

Patil, R.B. 2014. Maintenance of Reproductive Competency in Breeder Males. https:// en.engormix.com/poultry-industry/articles/ maintenance-reproductive-competencybreeder-t36267.htm [9 September 2020].

Prieto, M.T., J.L. Campo, \& J. Santiago-Moreno. 2011. Relationship among fluctuating asymmetry, morphological traits, and sperm quality in layers. Poul Sci 90:2845-2854.

Qazi, I.H., C. Angel, H. Yang, E. Zoidis, B. Pan, , Z. Wu, Z. Ming, C. Zeng, Q. Meng, $H$. Han, and G. Zhou. 2019. Role of Selenium and Selenoproteins in Male Reproductive Function: A Review of Past and Present Evidences. Antioxidants 8:268. 36 pp.

Ren, B., X. Cheng, D. Wu, S.Y. Xu, L.Q. Che, \& Z.F. Fang, 2015. Effect of different amino acid patterns on semen quality of boars fed with lowprotein diets. Anim Reprod Sci (1)61:96-103.

Revington, W.H., E.T. Moran, \& G.R. McDaniel. 1991. Performance of broiler breeder males given low protein feed. Poult Sci 70:139145.

Romero-Sanchez, H., P.W. Plumstead, N. Leksrisompong, K.E. Brannan, \& J. Brake. 2008. Feeding Broiler Breeder males. 4. Deficient feed allocation reduces fertil- ity and broiler progeny body weight. Poult Sci 8:805-811.

Saeid, J.M., A.K. Shanoon, \& M.M. Marbut. 2011. Effects of Zingiber officinale aqueous extract on semen characteristic and some blood plasma, semen plasma parameters in the broilers breeder male. Intl J Poult Sci 10:629633.

Saemi, F., M.J. Zamiri, A. Akhlaghi, M. Niakousari, M. Dadpasand, \& M.M. Ommati. 2012. Dietary inclusion of dried tomato pomace improves the seminal characteristics in Iranian native roosters. Poult Sci 91:2310-2315.

Sakumoto, R., K. Hayashi, \& T. Takahashi. 2014. Different expression of PGE synthase, PGF receptor, TNF, Fas and oxytocin in the bovine corpus luteum of the estrous cycle and pregnancy. Reprod Biol 14:115-121. 
Schmidt, A., B. Marescau, E.A. Boehm, W.K.J., Renema, R. Peco, \& A. Das. 2004. Severely altered guanidino compound levels, disturbed body weight homeostasis and impaired fertility in a mouse model of guanidinoacetate N-methyltransferase (GAMT) deficiency. Hum Mol Genet 13: 905-21.

Senger, P.L. 2003. Pathways to pregnancy and parturition. Current Concetions, Inc. Redmond OR, USA.

Shanmugam, M., B. Prakash, \& A.K. Panda. 2014. Effect of dietary organic zinc supplementation on semen quality in Dahlem Red roosters. Proceedings of Global Animal Nutrition Conference, Bengaluru (India), April 20-22. pp.234.

Shanmugam, M., B. Prakash, E.P.K. Reddy, \& A.K. Panda. 2015. Dietary organic zinc and selenium supplementation improves semen quality and fertility in layer breeders. Indian J Anim Sci 85(2):202-204.

Soi, M.N.J. 2016. Uji Viabilitas Spermatozoa Sapi Bali Jantan dengan Menggunakan Larutan Natrium Clorida $(\mathrm{NaCl})$ yang Berbeda Level. Journal of Animal Science (2):28-29.

Sönmez, M., G.C. Türk, A.O. Ceribas, F. Sakin, \& A. Atessahin. 2011. Attenuating effect of lycopene and ellagic acid on 2,3,7,8tetrachlorodibenzo-pdioxin-induced spermiotoxicity and testicular apoptosis. Drug Chem Toxic 34:347-356

Stanislavov, R., V. Nikolova, \& P. Rohdewald. 2009. Improvement of seminal parameters with Prelox: A randomized, double-blind, placebo-controlled, cross-over trial. Phototherapy Res 23 (3): 97-302.

Suchý, P., E. Straková, J. Illek, \& M. Simon. 1998. Effect of applications of various forms of zinc on gonad development in breeding cocks. Czech J Anim Sci 43:343-48.

Surai, P.F. 1999. Vitamin E in avian reproduction. Poultry and Avian Biology Reviews 10(1): $1-60$.

Surai, P.F. \& J. Taylor-Pickard. 2008. In: Current Advances inSe Research and Applications ( Surai PF and Taylor-Pickard J eds.). 1:221261. Wageningen Academic Publishers, Wageningen, The Netherlands.
Surai, P.F. \& V. Fisinin. 2014. Selenium in poultry breeder nutrition: an update. Anim Feed Sci Technol 191:1-15.

Surai, P.F., I.A. Ionov, E.F. Kuchmistova, R.C. Noble, \& B.K. Speake. 1998. The relationship between the levels of $\alpha$ tocopherol and carotenoids in the maternal feed, yolk and neonatal tissues: comparison between the chicken, turkey, duck and goose. J Sci Food Agric 76 (4):593-598.

Tabatabaei, S., M. Chaji, \& T. Mohammdabadi. 2010. Correlation between age of rooster and semen quality in iranian indigenous broiler breeder chickens. Journal of Animal And Veterinery Advance 9(1):195-198.

Tabatabaei, S., R. Batavani, E. Ayen, F. Sciences, \& R. Agriculture. 2011. Effects of vitamin E addition to chicken semen on sperm quality during in vitro storage of semen. Veterinary Research Forum 2:103-111.

Tadondjou, C.D., F. Ngoula, J.P. Kana, H.F. Defang, H.K. Mube, \& A. Teguia. 2013. Effect of dietary energy level on body weight, testicular development and semen quality of local barred chicken of the western highlands of Cameroon. Adv Reprod Sci 1(3):38-43.

Taniguchi, F., J.F. Couse, K.F. Rodriguez, J.M. Emmen, D. Poirier, \& K.S Korach. 2007. Estrogen receptor- $\alpha$ mediates an intraovarian negative feedback loop on thecal cell steroidogenesis via modulation of Cyp17a1 (cytochrome P450, steroid 17 $\alpha$ hydroxylase/17, 20 lyase) expression. The FASEB Journal 21:586-595.

Tapeh, R.S., M. Zhandi, M. Zaghari, \& A. Akhlaghi. 2016. Effects of guanidinoacetic acid diet supplementation on semen quality and fertility of broiler breeder roosters. Theriogenology 89:178-182.

Tesfay, H.H., Y. Sun, Y. Li, L. Shi, J. Fan, P. Wang, Y. Zong, A. Ni, H. Ma, A.I. Mani, \& J. Chen. 2020. Comparative studies of semen quality traits and sperm kinematic parameters in relation to fertility rate between 2 genetic groups of breed lines. Poultry Science DOI: 10.1016/j.psj.2020.06.088. https://www.sciencedirect.com/science/articl e/pii/ S0032579120305319 [19 September 2020]. 
Triques, G.E., A.B. De Cristo, M. Caneves, P.F.S Marques, A.M.B Junior, \&J.I.M. Fernandes. 2019. Effect of antioxidant supplementation in diets of roosters during the post-peak phase on reproduction and production characteristics of offspring. Cienc. Anim Bras Goiânia 20:1-13.

Turk, G., A. Atessahin, M. Sonmez, A. Yuce, \& A.O. Ceribasi. 2007. Lycopene protects against cyclosporin A-induced testicular toxicity in rats. Theriogenology 67:778-785.

Vigue, C., L. Vigue, \& G. Huszar. 1992. Adenosine triphosphate (ATP) concentrations and ATP/adenosine diphosphate ratios in human sperm of normospermic, oligospermic, and asthenospermic specimens and in their swimup fractions: lack of correlation between ATP parameters and sperm creatine kinase concentrations. J Androl 13:305-11.

Wahyuni, H.S., R. Setiawan, \& E. Sujana. 2017. Effects of energy-protein balance in the diet on semen characteristic of west java local ducks. In 2nd International Conference on Sustainable Agriculture and Food Security: A Comprehensive Approach, $\mathrm{KnE}$. Life Sciences. pages 118-126.

Walker, J.B. 1979. Creatine: biosynthesis, regulation, and function. Adv Enzymol Relat Areas Mol Biol 50:177-42.

Wang, F., S. Liu, Q. Sun, L. Zhang, Y. Song, \& W. Sheng. 2014. Urinary VEGF and PGE2 levels and the association with arsenical metabolites in copper-smelting workers. Occupational and Environmental Medicine 71(10):675-680. .
Wilson, J.L., L.M. Krista, G.R. McDaniel, \& C.D. Sutton. 1988. Correlation of broiler breeder male semen production and testes morphology. Poult Sci 67:660-668.

Wu, G., F. Bazer, T. Davis, S. Kim, P. Li, \& J. M. Rhoads. 2009. Arginine metabolism and nutrition in growth, health and disease. Amino Acids 37(1):153-168.

Xuan, N.T, N.V. Duy, D.T Nhung, \& V.D Ton. 2019. Dietary supplementation with sesame seeds to improve semen quality of ho cocks. VJAS 2(2):376-386.

Yan, W., C. Kanno, E. Oshima, Y. Kuzuma, S. W. Kim, H. Bai, M. Takahashi, Y. Yanagawa, M. Nagano, J. I. Wakamatsu, \& M. Kawahara. 2017. Enhancement of sperm motility and viability by turmeric byproduct dietary supplementation in roosters. Anim Reprod Sci 185:195-204.

Zhang, X., W.D. Berry, G.R. Mcdaniel, D.A. Roland, P. Liu, C. Calvert, \& R. Wilhite. 1999. Body weight and semen production of broiler breeder males as influenced by crude protein levels and feeding regimens during rearing. Poult Sci 78:190-196. 